УДК 595.762 .12

DOI: $10.18101 / 2542-0623-2019-4-52-73$

\title{
БАССЕЙНОВЫЙ ПОДХОД К ИЗУЧЕНИЮ ПРОСТРАНСТВЕННОЙ ОРГАНИЗАЦИИ ЖУКОВ-ЖУЖЕЛИЦ (НА ПРИМЕРЕ БАССЕЙНА РЕКИ ИВОЛГА — БАССЕЙНА ОЗЕРА БАЙКАЛ)
}

\section{Л. Ц. Хобракова}

\section{(C) Хобракова Лариса Цыренжаповна}

кандидат биологических наук,

Институт общей и экспериментальной биологии СО РАН

Россия, 670047, г. Улан-Удэ, ул. Сахьяновой, 6

E-mail: khobrakova77@mail.ru

Фауна жуков-жужелиц бассейна р. Иволга представляет собой типичную фауну переходной лесостепной зоны между сибирской тайгой и монгольской степью, которая сформировалась на стыке хребта Хамар-Дабан и Селенгинского среднегорья. Выявлено 148 видов жужелиц из 32 родов. На основе бассейновой концепции изучена пространственная организация жужелиц в бассейне р. Иволга (бассейновая система р. Селенга — оз. Байкал) в Западном Забайкалье. Выявлены ландшафтные комплексы жужелиц от истока до устья реки и от водораздела до поймы реки. В первом случае проведено районирование бассейна p. Иволга на основе локальных фаун жужелиц и фаунистических связей между ними. Выявлено 5 ландшафтных комплексов жужелиц на уровне урочищ: Верхнеиволгинское лугово-болотно-лесное, Мухинское лугово-болотное, Нижнеиволгинское лугово-степное, Большереченское лесостепное и Тапхарское степное. Фауна жужелиц Верхнеиволгинского урочища наиболее богатая (102 вида), в ней преобладают лесные виды, которые приурочены к верховью р. Иволга на южном склоне хр. Хамар-Дабан. В условиях повышенного увлажнения обитает реликт широколиственных лесов Carabus smaragdinus Fischer von Waldheim, 1823. Видовой состав жужелиц Мухинского урочища бедный (34 вида), он является переходной фауной между Верхнеиволгинской и Нижнеиволгинской урочищами. Здесь преобладают луговые и болотные виды жужелиц на берегах Мухинского болота, которое сформировалось на месте голоценового Мухинского праозера. В месте прорыва древнего озера в виде р. Иволга в Нижнеиволгинском урочище распространены степные, луговые и галофильные виды жужелиц (76 видов). В Большереченском (53 вида) и Тапхарском (55 видов) урочищах широко распространены степные виды жужелиц, которые, вероятно, проникли из Монголии по Селенгинскому миграционному коридору. Во втором случае выявлена катенарная смена комплексов жуков жужелиц от водораздела до поймы реки на северной и южной катенах. Комплексы жужелиц в элювиальной позиции обеих катен в сосновых сухих лесах характеризуются бедным видовым составом жужелиц (16-17 видов), низкой численностью (пара сотен экземпляров жуков) и низкой уловистостью жуков за сезон (0,1-0,2 экз. / лов.-сут.). В комплексе жужелиц транзитной позиции южной катены в полынной залежи зарегистрирована самая высокая численность и высокая уловистость (4109 эк3., 3,3 экз. / лов.-сут.). В комплексе жужелиц аккумулятивной позиции южной катены в чиевой степи на солонцах выявлен относительно богатый видовой состав (34 вида). В структуре доминирования почти во всех позициях катен преобладают степные виды и галофильные виды жужелиц, особенно из родов Harpalus и Poecilus. В условиях сухого климата, недостатка почвенного увлажнения и засоления почв в бассейне р. Иволга формируются аридные лесостепные комплексы жужелиц. 
Л. Ц. Хобракова. Бассейновый подход к изучению пространственной организации жуковжужелиц (на примере бассейна реки Иволга — бассейна озера Байкал)

Ключевые слова: бассейновый подход; бассейн р. Иволга; Западное Забайкалье; Селенгинское среднегорье; хребет Хамар-Дабан; жуки жужелицы (Coleoptera, Carabidae); районирование: урочище.

\section{Для цитирования}

Хобракова Л. Ц. Бассейновый подход к изучению пространственной организации жуков-жужелиц (на примере бассейна реки Иволга - бассейна озера Байкал) // Природа Внутренней Азии. Nature of Inner Asia. 2019. № 4(13). С. 52-73.

DOI: $10.18101 / 2542-0623-2019-4-52-73$

\section{Введение}

В горно-котловинных условиях Забайкалья сложно выделять и типизировать комплексы насекомых, в том числе жуков-жужелиц, в силу того, что регион находится в переходной лесостепной зоне взаимопроникновения сибирской тайги и монгольской степи, осложненной высотной поясностью. Для изучения пространственной организации жужелиц необходима научно обоснованная методологическая база, в качестве которой предлагается бассейновая концепция.

В основе бассейновой концепции лежит представление о речном бассейне как о саморегулирующейся, парадинамической и парагенетической геосистеме высокой степени целостности с четко выделенными границами на местности. Основные идеи бассейновой концепции широко используются в географических и ботанических исследованиях (Хортон, 1948; Мильков, 1981; Теоретические и методические проблемы сравнительной флористики, 1983; Фиськов, 1986; Шереметова, 2013; Корытный, Потапова, 2018 и др.). В энтомологических работах изучение пространственной организации насекомых чаще всего ограничивается привязкой к ландшафтам в долине реки или озера, различным формам рельефа в долине реки, таким как пойма, терраса, склоны, и реже всего к системам катен. Бассейновый подход объединяет эти разные способы пространственной дифференциации насекомых.

Наши исследования проведены на модельной группе жуков семейства жужелиц (Carabidae), которые разнообразны в таксономическом отношении и многочисленны в любых ландшафтах природных зон и высотных поясов и в своем жизненном цикле они тесно связаны с почвами (Гиляров, 1965; Шарова, 1981).

Цель нашей работы состоит в изучении пространственной организации жуков-жужелиц в бассейне р. Иволга (бассейновая система р. Селенга - оз. Байкал) в Западном Забайкалье. На основе бассейновой концепции выявить ландшафтные комплексы жужелиц в горизонтальном направлении от истока до устья реки Иволга и вертикальном или катенарном от водораздела до поймы реки.

Основные преимущества бассейнового подхода базируются на иерархической гидрологической сети разного уровня и четкой границе речных бассейнов в виде водоразделов, хорошо выделяемых на карте и местности. Бассейн реки отражает все разнообразие ландшафтов региона не только на уровне структуры, но и на уровне системообразующих связей (Бевз и др., 2014).

1) В первом случае разнообразие ландшафтов рассматривается на различных формах рельефа (пойма, коренные и придолинные склоны, овражно-балочные системы, конуса выноса, водораздельные плато) и водораздельных и долинно-речных группах морфологических элементов (типов местности и их вариантов, урочищ, фаций). 
2) Во втором случае разнообразие ландшафтов представлено посредством катенарных связей в рамках полосно-ярусного ряда ландшафтных комплексов и собственно бассейновых, формирующихся в результате гидрофункционирования.

Бассейны рек в зависимости от их величины отражают широтно-зональные осо-

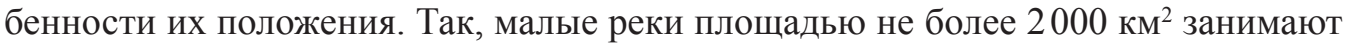
часть территории одной географической зоны, бассейны средних рек площадью

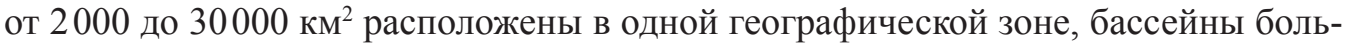

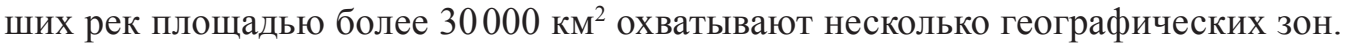
Бассейны малых и средних рек отражают как уникальные, так и типичные черты ландшафтной структуры региональных природно-территориальных комплексов. Бассейновый подход удобен для изучения разнообразия биоты в горно-котловинных условиях рельефа. В то же время бассейновый подход имеет ограничения к объектам изучения, это должны быть мелкие и желательно нелетающие или летающие на недалекие расстояния насекомые.

\section{Материалы и методы}

Исследования жуков-жужелиц проведены в бассейне р. Иволга, которая относится к рекам второго порядка в бассейновой системе р. Селенга - оз. Байкал. Бассейн

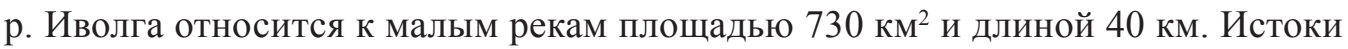
реки начинаются в южных предгорьях хр. Хамар-Дабан, по большей части река протекает по Иволгинской котловине, которая является частью системы котловин Селенгинского среднегорья. Бассейн р. Иволга представляет собой пример переходной лесостепной зоны. Климат территории засушливый (200-250 мм), а почвы характеризуются засоленностью $(0,872-1,815 \%)$.

В бассейне р. Иволга изучено 22 биотопа с мая по октябрь 2009 г. и охватывает верховье и низовье р. Иволга, в ее средней части Мухинские болота, ее притоки Большая Речка, Халюта, а также Тапхарскую бессточную котловину, которая отделена небольшим увалом от Иволгинской котловины. Выявлено 96 видов жужелиц из 22 родов общей численностью 26321 экземпляр. В целом, по коллекционным данным ИОЭБ СО РАН, литературным и собственным сведениям, нами выявлено 148 видов жужелиц (Имехенова, 1980; Хобракова, 2012; Хобракова и др., 2015; Хобракова, Шиленков, Дудко, 2014).

Насекомые собраны почвенными ловушками по 20 штук в каждом биотопе через каждые 5 м. В качестве фиксатора использовали 4\%-ный раствор формалина. Материал выбирался каждые 10 дней в течение всего вегетационного сезона.

Всего известно 17 локальных точек сбора жужелиц: Большая Речка, Малая Речка, Гурульба, Ганджиево, Большой Ельник, Верхняя Иволга, Калёново, Нижняя Иволга, Иволгинская степь, Хубисхал, Иволгинск, Исток, Сужа, Мухино, Тапхар, Красноярово, Халюта. В рамках бассейновой концепции все имеющиеся данные о жужелицах в бассейне р. Иволга соотнесли по гидрологической сети от ее истока до устья. В итоге они объединились в 7 локальных фаун жужелиц - Мухино, Большая Речка, Верхняя Иволга, Нижняя Иволга, Тапхар, Халюта, Красноярово. На основе данных матриц пересечений и включений локальных фаун жужелиц нами построен ориентированный граф сходства локальных фаун. Выбираем пороги включения так, чтобы желательно все локалитеты жужелиц оказались связанными между собой. Обычно если данных 
Л. Ц. Хобракова. Бассейновый подход к изучению пространственной организации жуковжужелиц (на примере бассейна реки Иволга — бассейна озера Байкал)

достаточно и они равномерные по локалитетам, то мера включения начинается от 70\% и выше. Можно использовать два и более пороговых значения для выявления различных связей, наибольшие значения трактуются как главные, наименьшие как второстепенные. На основе орграфа и фаунистических связей между локалитетами жужелиц проводим районирование бассейна р. Иволга и выявляем дифференциацию комплексов жужелиц на уровне урочищ от верховья до низовья реки. Этот метод позволяет выявить разнообразие комплексов жужелиц в бассейне реки и характерные виды для урочищ. На основе фауны, ландшафтов и их исторического прошлого можно проводить реконструкцию фауны и выявлять пути формирования.

Для выявления катенарного распределения жужелиц от водораздела до поймы p. Иволга нами заложены катены на ее северном и южном бортах с использованием принципов зонально-катенного метода (Мордкович, Любечанский, 1998). Северная катена расположена по направлению Шаманские горы - Тапхарская котловина, южная катена рассмотрена по направлению южные отроги хр. Хамар-Дабан Иволгинская котловина - Мухинские болота (табл. 1). Сборы жуков проводились через каждые 10 дней с 30.05. по 30.09.2009 г.

Таблица 1

Биотопы на катенах от водораздела до поймы р. Иволга

\begin{tabular}{|c|c|c|c|c|c|}
\hline Код & Биотопы & $\begin{array}{l}\text { Позиция } \\
\text { в катене }\end{array}$ & $\begin{array}{c}\text { Географические } \\
\text { координаты }\end{array}$ & $\begin{array}{l}\text { Высота, } \\
\text { м н.у.м. }\end{array}$ & $\begin{array}{c}\text { Время сбора } \\
\text { материала }\end{array}$ \\
\hline \multicolumn{6}{|c|}{ Северная катена «Шаманские горы - Тапхарская котловина» } \\
\hline Т 12 & $\begin{array}{l}\text { Сосновый редкостойный } \\
\text { коржинскоосоковый лес, } \\
\text { Ганзуринский хребет, } \\
\text { Тапхарская котловина }\end{array}$ & $Э$ & $\begin{array}{c}51^{\circ} 40^{\prime} 933^{\prime \prime} \mathrm{N} \\
107^{\circ} 20^{\prime} 267^{\prime \prime} \mathrm{E}\end{array}$ & 729 & $\begin{array}{c}30.05- \\
30.09 .2009\end{array}$ \\
\hline Т 11 & $\begin{array}{l}\text { Заросли шиповника, } \\
\text { Ганзуринский хребет, } \\
\text { Тапхарская котловина }\end{array}$ & $\mathrm{TB}$ & $\begin{array}{l}51^{\circ} 41^{\prime} 007^{\prime \prime} \mathrm{N} \\
107^{\circ} 20^{\prime} 189^{\prime \prime} \mathrm{E}\end{array}$ & 727 & $\begin{array}{c}30.05- \\
30.09 .2009\end{array}$ \\
\hline Т 10 & $\begin{array}{l}\text { Степь крыловоковыльно- } \\
\text { растопыренно-змеевковая } \\
\text { настоящая, Тапхарская } \\
\text { котловина }\end{array}$ & Tc & $\begin{array}{l}51^{\circ} 43^{\prime} 300^{\prime \prime} \mathrm{N} \\
107^{\circ} 21^{\prime} 172^{\prime \prime} \mathrm{E}\end{array}$ & 563 & $\begin{array}{c}30.05- \\
30.09 .2009\end{array}$ \\
\hline T 8 & $\begin{array}{l}\text { Ильмовник в транзитной } \\
\text { части, Тапхарская котловина }\end{array}$ & $\mathrm{T}_{\mathrm{H}}$ & $\begin{array}{l}51^{\circ} 44^{\prime} 445^{\prime \prime} \mathrm{N} \\
107^{\circ} 20^{\prime} 549^{\prime \prime} \mathrm{E}\end{array}$ & 535 & $\begin{array}{c}30.05- \\
30.09 .2009\end{array}$ \\
\hline Т 7 & $\begin{array}{l}\text { Залежь полынная на днище, } \\
\text { Тапхарская котловина }\end{array}$ & A & $\begin{array}{l}51^{\circ} 44^{\prime} 353^{\prime \prime} \mathrm{N} \\
107^{\circ} 20^{\prime} 397^{\prime \prime} \mathrm{E}\end{array}$ & 513 & $\begin{array}{c}10.06- \\
20.09 .2009 \\
\end{array}$ \\
\hline \multicolumn{6}{|c|}{ Южная катена «Отроги хр. Хамар-Дабан - Иволгинская котловина» } \\
\hline ТНИ 1 & $\begin{array}{l}\text { Сосновый лес } \\
\text { среднетаволгово-осоковый, } \\
\text { р. Большая Речка, } \\
\text { Иволгинская котловина }\end{array}$ & $Э$ & $\begin{array}{c}51^{\circ} 50^{\prime} 478^{\prime \prime} \mathrm{N} \\
107^{\circ} 22^{\prime} 196^{\prime \prime} \mathrm{E}\end{array}$ & 775 & $\begin{array}{c}30.05- \\
20.09 .2009\end{array}$ \\
\hline ТНИ 2 & $\begin{array}{l}\text { Степь водосборолистно- } \\
\text { стоповидноосоковая с } \\
\text { участием спиреи, окр. пос. } \\
\text { Гурульба, Иволгинская } \\
\text { котловина }\end{array}$ & Тв & $\begin{array}{l}51^{\circ} 50^{\prime} 960^{\prime \prime} \mathrm{N} \\
107^{\circ} 23^{\prime} 135^{\prime \prime} \mathrm{E}\end{array}$ & 603 & $\begin{array}{c}30.05- \\
30.09 .2009\end{array}$ \\
\hline
\end{tabular}




\begin{tabular}{|c|c|c|c|c|c|}
\hline ТНИ 4 & $\begin{array}{l}\text { Степь настоящая } \\
\text { крыловоковыльно- } \\
\text { холоднополынно- } \\
\text { бесстебельнолапчатковая, } \\
\text { окр. пос. Гурульба, } \\
\text { Иволгинская котловина } \\
\end{array}$ & Tc & $\begin{array}{c}51^{\circ} 50^{\prime} 074^{\prime \prime} \mathrm{N} \\
107^{\circ} 23^{\prime} 163^{\prime \prime} \mathrm{E}\end{array}$ & 579 & $\begin{array}{c}30.05- \\
30.09 .2009 \\
\end{array}$ \\
\hline ТНИ 5 & $\begin{array}{l}\text { Залежь полынная, окр. пос. } \\
\text { Гурульба, Иволгинская } \\
\text { котловина }\end{array}$ & TH & $\begin{array}{c}51^{\circ} 49^{\prime} 569^{\prime \prime} \mathrm{N} \\
107^{\circ} 23^{\prime} 050^{\prime \prime} \mathrm{E}\end{array}$ & 560 & $\begin{array}{c}10.06- \\
30.09 .2009\end{array}$ \\
\hline X 4 & $\begin{array}{l}\text { Луг чиевый, окр. пос. } \\
\text { Хубисхал, Иволгинская } \\
\text { котловина }\end{array}$ & A & $\begin{array}{c}51^{\circ} 46^{\prime} 427^{\prime \prime} \mathrm{N} \\
107^{\circ} 22^{\prime} 797^{\prime \prime} \mathrm{E}\end{array}$ & 514 & $\begin{array}{c}30.05- \\
30.09 .2009 \\
\end{array}$ \\
\hline ТНИ 8 & $\begin{array}{l}\text { Луг разнотравно- } \\
\text { ползунково-осоковый } \\
\text { солонцеватый, северный } \\
\text { берег Мухинских болот, } \\
\text { Иволгинская котловина }\end{array}$ & CA & $\begin{array}{c}50^{\circ} 48^{\prime} 166^{\prime \prime} \mathrm{N} \\
107^{\circ} 21^{\prime} 266^{\prime \prime} \mathrm{E}\end{array}$ & 503 & $\begin{array}{c}10.06- \\
30.09 .2009\end{array}$ \\
\hline
\end{tabular}

\section{Результаты и обсуждение}

Ландшафтные комплексы жужелии В бассейне р. Иволга на уровне урочиш

Бассейновый подход позволил выявить разнообразие комплексов жужелиц во всех основных ландшафтах в бассейне р. Иволга в горизонтальном направлении от истока до ее устья. В бассейне р. Иволга выявлено 148 видов из 32 родов жужелиц. Большинство таксонов жужелиц относятся к родам Harpalus (31), Amara (21), Carabus (15), Pterostichus (15) и Curtonotus (9).

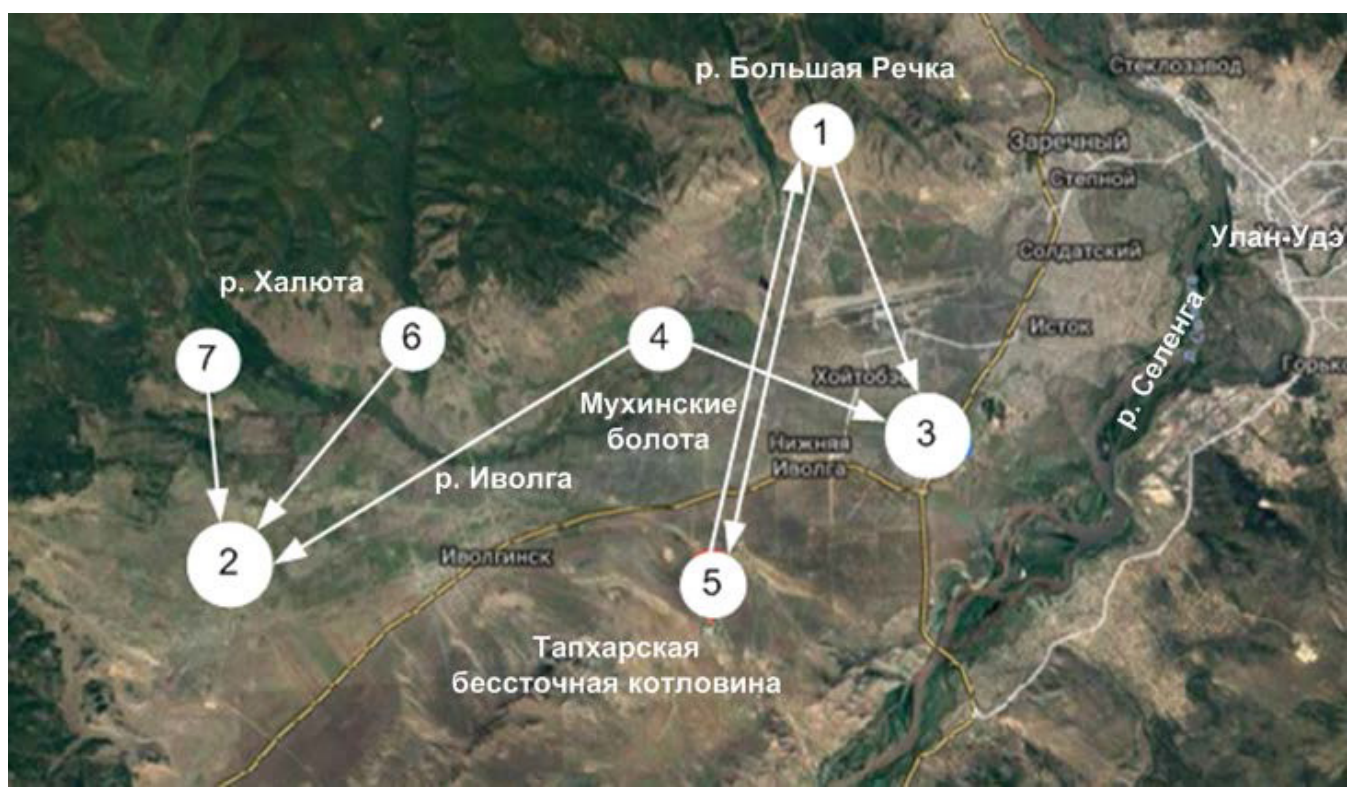

Puc. 1. Ориентированный граф сходства локальных фаун жужелиц в бассейне р. Иволга (>70\%)

Примечание: 1 - Большая Речка, 2 - Верхняя Иволга, 3 - Нижняя Иволга, 4 - Мухинские болота, 5- Тапхар, 6 - Красноярово, 7 - Халюта. 
Л. Ц. Хобракова. Бассейновый подход к изучению пространственной организации жуковжужелиц (на примере бассейна реки Иволга — бассейна озера Байкал)

В бассейне р. Иволга выявлено 7 локальных фаун жужелиц, приуроченных к рекам третьего порядка Большая Речка и Халюта, болотам Мухино и Красноярово, верховью и низовью р. Иволга и бессточной котловине Тапхар. Анализ фаунистических связей между локальными фаунами жужелиц позволил провести ландшафтное районирование бассейна р. Иволга и выделить пять урочищ: Верхнеиволгинское лугово-болотно-таежное, Мухинское лугово-болотное, Нижнеиволгинское луговостепное галофитное, Большереченское лесостепное и Тапхарское степное (рис. 1).

При пороге сходства больше $70 \%$ все локалитеты между собой имеют тесные связи, особенно выделяется Иволгинская котловина, где Мухинские болота являются центральной связкой между верховьем и низовьем р. Иволга. Тапхарское урочище выглядит более обособленным от Иволгинской котловины, но имеется его связь только с Большереченским урочищем. В этих урочищах произрастают сосновые сухие леса на останцовых Шаманских горах и на южных предгорьях Хамар-Дабана и горные степи на террасах и конусах выносов.

Современная фауна жуков жужелиц (Coleoptera, Carabidae) бассейна малой p. Иволга сформировалась на орографическом стыке хребта Хамар-Дабан и Селенгинского среднегорья, и выделенные комплексы жужелиц представляют собой типичную фауну лесостепной переходной зоны между тайгой и степью в бассейне оз. Байкал (табл. 2).

Таблица 2

Таксономический состав локальных фаун жужелиц в бассейне р. Иволга

\begin{tabular}{|c|c|c|c|c|c|c|c|}
\hline Таксономический состав & 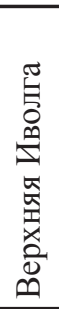 & 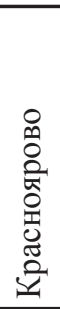 & 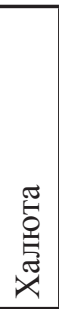 & 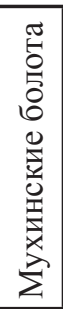 & 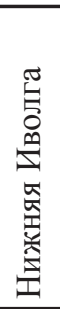 & 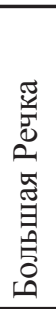 & 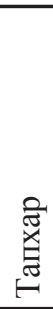 \\
\hline Cylindera obliquefasciata M.F. Adams, 1817 & + & & & + & + & & + \\
\hline C. gracilis (Pallas, 1773) & + & & & & & + & \\
\hline C. mongolica (Faldermann, 1835) & & & & & + & + & \\
\hline Cicindela coerulea nitida Lichtenstein, 1796 & + & & & & & & + \\
\hline C. transbaicalica Motschulsky, 1844 & & & & & & & + \\
\hline C. sylvatica Linnaeus, 1758 & + & + & & & & & \\
\hline Nebria livida angulata Bänninger, 1949 & + & + & & & & & \\
\hline N. subdilatata Motschulsky, 1844 & + & & & & & & \\
\hline N. catenulata Fischer von Waldheim, 1820 & + & & & & & & \\
\hline Calosoma denticolle Gebler, 1833 & & & & + & + & + & + \\
\hline Carabus arcensis conciliator Fischer von Waldheim, 1822 & + & & + & & & & \\
\hline C. granulatus duarius Fischer von Waldheim, 1844 & + & & & + & + & & \\
\hline C. aeruginosus Fischer von Waldheim, 1820 & + & & & & & & \\
\hline C. hummeli stolidus Lapouge, 1924 & + & + & & & & & \\
\hline
\end{tabular}


NATURE OF INNER ASIA

\begin{tabular}{|c|c|c|c|c|c|c|c|}
\hline C. henningi henningi Fischer von Waldheim, 1817 & + & + & & & & & \\
\hline C. odoratus odoratus Motschulsky, 1844 & + & & & & & & \\
\hline C. odoratus irkoutskensis Lapouge, 1915 & + & & & & & & \\
\hline C. odoratus dabanensis Shilenkov, 1996 & + & & & & & & \\
\hline C. regalis Fischer von Waldheim, 1820 & + & & & & & & \\
\hline C. latreillei Fischer von Waldheim, 1820 & + & & & & + & + & + \\
\hline C. maeander Fischer von Waldheim, 1820 & + & + & & + & + & + & \\
\hline C. canaliculatus canaliculatus Adams, 1812 & + & + & & & & + & + \\
\hline C. kruberi Fischer von Waldheim, 1822 & + & & & & + & + & + \\
\hline $\begin{array}{l}\text { C. smaragdinus smaragdinus Fischer von Waldheim, } \\
1823\end{array}$ & + & + & + & & + & & \\
\hline C. glyptopterus Fischer von Waldheim, 1828 & + & & & & + & + & + \\
\hline Blethisa multipunctata (Linnaeus, 1758) & & & & + & & & \\
\hline B. tuberculata Motschulsky, 1844 & + & & & & & & \\
\hline Elaphrus splendidus Fischer von Waldheim, 1828 & + & & & & & & \\
\hline E. sibiricus Motschulsky, 1844 & + & & & & + & & \\
\hline E. cupreus Duftschmid, 1812 & & & & + & + & & \\
\hline E. riparius (Linnaeus, 1758) & + & & & & & & \\
\hline Loricera pilicornis (Fabricius, 1775) & + & + & & & + & & \\
\hline Trechus secalis (Paykull, 1790) & & & + & & & & \\
\hline Bembidion lampros (Herbst, 1784) & + & & & & & & \\
\hline B. obliquum Sturm, 1825 & & & & & + & & \\
\hline B. ovale (Motschulsky, 1844) & & & & & + & & \\
\hline Poecilus versicolor (Sturm, 1824) & + & & & + & + & + & + \\
\hline P. fortipes (Chaudoir, 1850) & + & & & + & + & + & + \\
\hline P. gebleri Dejean, 1828 & + & + & & + & + & + & + \\
\hline P. reflexicollis (Gebler, 1830) & + & + & & & + & & \\
\hline P. major (Motschulsky, 1844) & & & & + & + & & + \\
\hline Pterostichus eschscholtzii (Germar, 1824) & + & & & + & + & + & \\
\hline Pt. niger Schaller, 1783 & + & & & + & & & \\
\hline Pt. planipennis R. F. Sahlberg, 1844 & & & & + & + & & \\
\hline Pt. interruptus Dejean, 1828 & + & + & & & & & \\
\hline Pt. gibbicollis (Motschulsky, 1844) & & + & & & + & + & \\
\hline Pt. haptoderoides (Tschitscherine, 1888) & + & & & + & & & \\
\hline Pt. laticollis (Motschulsky, 1844) & & & & + & + & & \\
\hline Pt. diligens (Sturm, 1824) & + & & + & & & + & \\
\hline Pt. morawitzianus (Lutshnik, 1922) & + & + & + & & & & \\
\hline Pt. orientalis orientalis (Motschulsky, 1844) & + & & & & & & \\
\hline Pt. discrepans A. Morawitz, 1862 & & & & + & & & \\
\hline
\end{tabular}


Л. Ц. Хобракова. Бассейновый подход к изучению пространственной организации жуковжужелиц (на примере бассейна реки Иволга — бассейна озера Байкал)

\begin{tabular}{|c|c|c|c|c|c|c|c|}
\hline Pt. adstrictus Eschscholtz, 1823 & + & + & & & & + & \\
\hline Pt. oblongopunctatus (Fabricius, 1787) & + & & & & + & + & \\
\hline Pt. magus mongolicus (Motschulsky, 1844) & + & & & & & & \\
\hline Pt. dilutipes (Motschulsky, 1844) & + & + & & & & + & \\
\hline Calathus melanocephalus (Linnaeus, 1758) & & + & & & & & \\
\hline Cal. micropterus (Duftschmid, 1812) & & + & & & & & \\
\hline $\begin{array}{l}\text { Pseudotaphoxenus dauricus dauricus (Fischer von Wald- } \\
\text { heim, 1823) }\end{array}$ & + & + & & & + & + & + \\
\hline Agonum gracilipes (Duftschmid, 1812) & + & + & & & + & + & + \\
\hline Ag. fuliginosum (Panzer, 1809) & + & & + & & & & \\
\hline Ag. dolens (C.R. Sahlberg, 1827) & + & & & & + & + & + \\
\hline Ag. impressum (Panzer, 1797) & + & & & + & + & + & + \\
\hline Ag. sexpunctatum (Linnaeus, 1758) & + & & & + & & & \\
\hline Ag. viduum (Panzer, 1797) & + & & & + & & & \\
\hline Platynus assimilis (Paykull, 1790) & + & & & & & & \\
\hline Platynus mannerheimi Dejean, 1828 & + & & + & & & & \\
\hline Synuchus vivalis (Illiger, 1798) & + & & & & & & \\
\hline Syn. congruus (A. Morawitz, 1862) & + & & & & & & \\
\hline Pristosia nitidula (A. Morawitz, 1862) & & & & & & + & + \\
\hline Amara aenea (De Geer, 1774) & & + & & & & & + \\
\hline A. anxia Tschitschérin, 1898 & & & & & & & + \\
\hline A. biarticulata Motschulsky, 1844 & & & & & & + & + \\
\hline A. communis (Panzer, 1797) & + & + & & & + & & \\
\hline A. nitida Sturm, 1825 & & + & & & & & \\
\hline A. orienticola Lutshnik, 1935 & + & & & & & & \\
\hline A. ovata (Fabricius, 1792) & & & & & + & & + \\
\hline A. similata (Gyllenhal, 1810) & + & & & & & & \\
\hline A. violacea Motschulsky, 1844 & & & & & & + & + \\
\hline A. interstitialis Dejean, 1828 & + & & & & & & \\
\hline A. praetermissa (C. R. Sahlberg, 1827) & + & & & & & & \\
\hline A. infima (Duftschmid, 1812) & & & & & & & + \\
\hline A. rupicola (C. Zimmermann, 1832) & & & & & + & + & + \\
\hline A. saginata vilis Tschitscherin, 1894 & & + & & & + & & + \\
\hline A. apricaria (Paykull, 1790) & + & & & & + & & \\
\hline A. majuscula (Chaudoir, 1850) & + & & & & & & \\
\hline A. equestris (Duftschmid, 1812) & + & & & & & & \\
\hline A. infuscata (Putzeys, 1866) & + & + & & & & & \\
\hline A. abdominalis (Motschulsky, 1844) & & & & & + & & \\
\hline A. microdera (Chaudoir, 1844) & & & & & & & + \\
\hline
\end{tabular}


NATURE OF INNER ASIA

\begin{tabular}{|c|c|c|c|c|c|c|}
\hline A. stulta Lutshnik, 1935 & & & & + & & \\
\hline Curtonotus brevicollis (Chaudoir, 1850) & & & & + & + & + \\
\hline Curt. dauricus (Motschulsky, 1844) & + & & + & + & & \\
\hline Curt. dux Tschitscherin, 1894 & & & + & + & + & \\
\hline Curt. fodinae (Mannerheim, 1825) & + & & & + & + & + \\
\hline Curt. giganteus (Motschulsky, 1845) & & & + & + & + & + \\
\hline Curt. harpaloides (Dejean, 1828) & & & & + & + & + \\
\hline Curt. hyperboreus (Dejean, 1831) & + & & & & & \\
\hline Curt. shinanensis (Habu, 1953) & & & & & & + \\
\hline Curt. torridus (Panzer, 1796) & & & & + & & \\
\hline Bradycellus glabratus (Reitter, 1894) & & & & & + & + \\
\hline Harpalus calceatus (Duftschmid, 1812) & + & & + & + & + & + \\
\hline H. major Motschulsky, 1850 & & & & & & + \\
\hline H. pusillus Motschulsky, 1850 & + & + & & + & + & \\
\hline H. acupalpoides Reitter, 1900 & & & & + & & + \\
\hline H. anxius (Duftschmid, 1812) & + & & & & & \\
\hline H. amariformis Motschulsky, 1844 & + & + & & + & + & + \\
\hline H. amplicollis Ménétriés, 1848 & + & & & + & + & + \\
\hline H. tichonis Jacobson, 1907 & & & & + & + & + \\
\hline H. macronotus Tschitscherine, 1893 & & & & + & + & + \\
\hline H. zabroides Dejean, 1829 & + & & & & & \\
\hline H. brevis Motschulsky, 1844 & + & & & & & \\
\hline H. brevicornis Germar, 1824 & + & + & + & + & + & + \\
\hline H. froelichi (Sturm, 1818) & + & + & & + & + & + \\
\hline H. latus (Linnaeus, 1758) & & & & & & + \\
\hline H. solitaris (Dejean, 1829) & & & & + & & \\
\hline H. rufiscapus (Gebler, 1833) & & & & + & & \\
\hline H. vittatus vittatus Gebler, 1833 & + & & + & + & + & + \\
\hline H. fuscipalpis (Sturm, 1818) & + & + & & + & & \\
\hline H. viridanus Motschulsky, 1844 & + & & & + & + & + \\
\hline H. lederi Tschitschérine, 1899 & + & & & & & \\
\hline H. smaragdinus (Duftschmid, 1812) & + & & & & & \\
\hline H. pallidipennis A. Morawitz, 1862 & + & + & + & + & + & + \\
\hline H. aequicollis Motschulsky, 1844 & + & & & & + & \\
\hline H. heyrovskyi Jedlička, 1928 & & & & + & + & + \\
\hline H. optabilis (Dejean, 1829) & & & & + & + & + \\
\hline H. salinus klementzae Kataev, 1984 & + & & & & & \\
\hline H. lumbaris (Mannerheim, 1825) & + & + & + & + & + & + \\
\hline H. affinis (Schrank, 1781) & + & + & + & & + & + \\
\hline
\end{tabular}


Л. Ц. Хобракова. Бассейновый подход к изучению пространственной организации жуковжужелиц (на примере бассейна реки Иволга — бассейна озера Байкал)

\begin{tabular}{|c|c|c|c|c|c|c|c|}
\hline H. erosus (Mannerheim, 1825) & + & & & & + & + & + \\
\hline H. amputatus obtusus Gebler, 1833 & + & + & & + & + & + & + \\
\hline H. distinguendus distinguendus (Duftschmid, 1812) & + & + & & + & + & + & \\
\hline Neophygas microcephalus (Faldermann, 1835) & & & & & + & + & \\
\hline Panagaeus cruxmajor (Linnaeus, 1758) & & & & & + & & \\
\hline Chlaenius stschukini Ménétriés, 1837 & & & & + & + & & \\
\hline Ch. tristis reticulatus Motschulsky, 1844 & + & + & & + & + & & \\
\hline Ch. alutaceus Gebler, 1829 & + & + & + & + & & & \\
\hline Masoreus wetterhallii Gyllenhal, 1813 & & & & & + & & \\
\hline Corsyra fusula (Steven in Dejean, 1825) & + & + & & + & + & + & + \\
\hline Lionedya mongolica (Motschulsky, 1850) & + & & & & & & + \\
\hline Dromius quadraticollis A. Morawitz, 1862 & & & & & + & & \\
\hline Syntomus mongolicus (Motschulsky, 1844) & & & & & + & & \\
\hline Microlestes minutulus Goeze, 1777) & & & & & + & & \\
\hline M. schroederi Holdhaus, 1912 & & & & & + & & \\
\hline Cymindis rivularis Motschulsky, 1844 & & & & & + & & \\
\hline Cym. faldermanni Gistel, 1838 & + & & & & & & \\
\hline Cym. collaris Motschulsky, 1844 & & + & & & & & + \\
\hline Cym. binotata Fischer von Waldheim, 1820 & + & + & & & + & + & + \\
\hline Cym. equestris Gebler, 1825 & & & & & + & & \\
\hline Cym. vaporariorum (Linnaeus, 1758) & + & & & & & & + \\
\hline Итого & 95 & 39 & 8 & 34 & 76 & 53 & 55 \\
\hline
\end{tabular}

КОМПЛЕКСЫ ЖУЖЕЛИЦ ВЕРХНЕ-ИВОЛГИНСКОГО ЛУГОВО-БОЛОТНО-ЛЕСНОГО УРОЧИЩА (ЛОкальные фауны Верхняя Иволга, Красноярово и Халюта) приурочены к верховью p. Иволга на южном склоне предгорий Хамар-Дабана. Многочисленная речная сеть Иволги, пересеченная оросительными каналами, сформировала условия повышенного увлажнения почвенного покрова. Здесь представлены экосистемы горной тайги с заболоченными ельниками, березняками вдоль оросительной системы, болотами и лугами на высотах 575-584 м н.у. м. Видовой состав жужелиц богатый (102 вида), из них 44 вида характерны только для этого урочища: Cicindela sylvatica, Nebria livida, N. subdilatata, N. catenulata, Carabus arcensis, C. aeruginosus, C. hummeli, C. henningi, C. odoratus, C. regalis, C. smaragdinus, B. tuberculata, Elaphrus splendidus, E. riparius, Trechus secalis, Bembidion lampros, Pterostichus interruptus, Pt. morawitzianus, Pt. orientalis, Pt. magus mongolicus, Calathus melanocephalus, Cal. micropterus, Agonum fuliginosum, Platynus assimilis, Pl. mannerheimi, Synuchus vivalis, S. congruus, Amara nitida, A. orienticola, A. similata, A. interstitialis, A. praetermissa, A. majuscula, A. equestris, A. infuscata, Curtonotus hyperboreus, Harpalus anxius, H. zabroides, H. brevis, H. lederi, H. smaragdinus, H. salinus klementzae, Cymindis faldermanni.

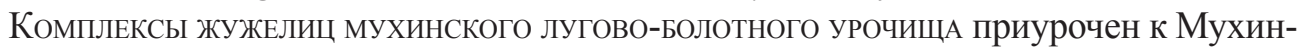
ским болотам, которые сформировались на месте прорыва голоценового озера. Этот 
комплекс приурочен к центральной части Иволгинской котловины (503-510 м н.у.м.). На разнотравно-бледноосоковых заболоченных солонцеватых лугах Мухинских болот обитают 34 вида жужелиц. Для этого урочища характерны лугово-болотные и болотные виды, такие как Carabus granulatus, C. maeander, Blethisa multipunctata, Pterostichus niger, Pt. discrepans, Agonum sexpunctatum, Ag. viduum, Chlaenius tristis, Ch. alutaceus.

КОМПЛЕКСЫ ЖУЖЕЛИЦ НИЖНЕ-ИВОЛГИНСКОГО ЛУГОВО-СТЕПНОГО ГАЛОФИТНОГО УРОчищА приурочены к низовью р. Иволга от поселков Хубисхал до Сужи. В этой части Иволгинской котловины широко распространены засоленные территории на поймах и низких террасах реки, на которых распространены разнообразные луга бескильницево-осоковые, бескильницево-ползунково-осоковые, заболоченные, галофитные, остепненные, степи ковыльно-разнотравные и чиевые, залежи люцерно-ковыльные, солончаки (502-526 м н.у.м.). Отмечено 76 видов жужелиц, из них 15 видов характерны для низовья р. Иволги - Bembidion obliquum, $B$. ovale, Amara abdominalis, A. stulta, Curt. torridus, Harpalus solitaris, H. rufiscapus, Panagaeus cruxmajor, Dromius quadraticollis, Syntomus mongolicus, Microlestes minutulus, M. schroederi, Cymindis rivularis, Cym. equestris. Находки из этого урочища Masoreus wetterhallii, Microlestes schroederi стали первыми для территории Бурятии.

КОМПЛЕКСЫ ЖУЖЕЛИЦ БОЛЬШЕРЕчЕНСКОГО ЛЕСОСТЕПНОГО УРОчИЩА ПриУроченЫ К бассейну р. Большая Речка, левого притока р. Иволга, берущей начало с южных предгорий Хамар-Дабана. Здесь распространены леса сосновые таволгово-петрофитноразнотравные, степи ковыльные с зарослями таволги на убурах, распаханные и деградированные долинные степи, уремы березово-елово-хвощевые в устье реки (529-775 м н.у.м.). Для этого урочища отмечено 53 вида жужелиц. Здесь не отмечены виды, присущие только для этого урочища, но имеются характерные виды, такие как Cylindera gracilis, Cyl. mongolica, Calosoma denticolle, Carabus latreillei, C. kruberi, Pristosia nitidula, Poecilus fortipes, Pterostichus oblongopunctatus, Curtonotus dux.

КОМПЛЕКСЫ ЖУЖЕЛИЦ ТАПХАРСКОГО СТЕПНОГО УРОчИЩА ПрИУрочеНЫ К ТаПХарскоЙ бессточной котловине, отделенной от Иволгинской котловины небольшим возвышением. Террасы и холмисто-грядовые возвышенности в этой котловине сложены преимущественно мощными песчаными и супесчаными отложениями Кривоярской свиты (Базаров, 1986). Ландшафтные особенности в бессточной котловине обусловили формирование сухостепного ландшафта на высотах 513-775 м н.у.м. К останцовым отрогам Шаманских гор приурочены леса сосновые таволговопетрофитно-разнотравные, на склонах хребта распространены леса сосновые с участием зарослей шиповника. На бортах Тапхарской котловины широко распространены степи ковыльные и мелкозлаково-чабрецовые на каштановых мучнистокарбонатных почвах и днище котловины - полынные залежи на солончаковых почвах. В этой котловине встречаются крупные заросли ильмовников, которые более широко представлены в Восточном Забайкалье, Монголии и Северном Китае (Рещиков, 1961; Фадеева, 1963). Здесь отмечено 55 видов жужелиц, из них 6 видов присущи для Тапхарской котловины - Amara anxia, A. infima, A. microdera, Curt. shinanensis, Harpalus major, H. latus. Отмечены характерные виды, такие как Carabus glyptopterus, Pterostichus adstrictus, Amara anxia, A. infima, A. microdera, Curt. shinanensis, Harpalus major, H. latus, Lionedya mongolica. 
Л. Ц. Хобракова. Бассейновый подход к изучению пространственной организации жуковжужелиц (на примере бассейна реки Иволга — бассейна озера Байкал)

ЛАНДШАФТНЫЕ КОМПЛЕКСЫ ЖУЖЕЛИЦ В БАССЕЙНЕ Р. ИВОЛГА НА КАТЕНАРНОМ УРОВНЕ

Выявлены особенности видового состава и вертикальной смены комплексов жужелиц на катенах северного и южного бортов бассейна р. Иволга от их водораздела к пойме (табл. 3). На формирование катенарных комплексов жужелиц сильное влияние оказывают аридный климат и засоленность почв. Характеристики позиций катен в бассейне р. Иволга соответствуют аридным регионам (Мордкович, 2005). Почти на всех позициях катен доминируют степные и галофильные виды жужелиц, особенно из рода Harpalus и Poecilus, кроме элювиальной позиции северной катены, где преобладает лесной Carabus canaliculatus.

Комплексы жужелиц рассмотренных катен отличаются числом позиций в катене. На северной катене представлены комплексы жужелиц трех позиций (элювиальной, транзитной и аккумулятивной) в связи с их положением в Тапхарской бессточной котловине. В то время как на южной катене число позиций увеличивается до четырех за счет супераквальной позиции на Мухинских болотах (рис. 2).

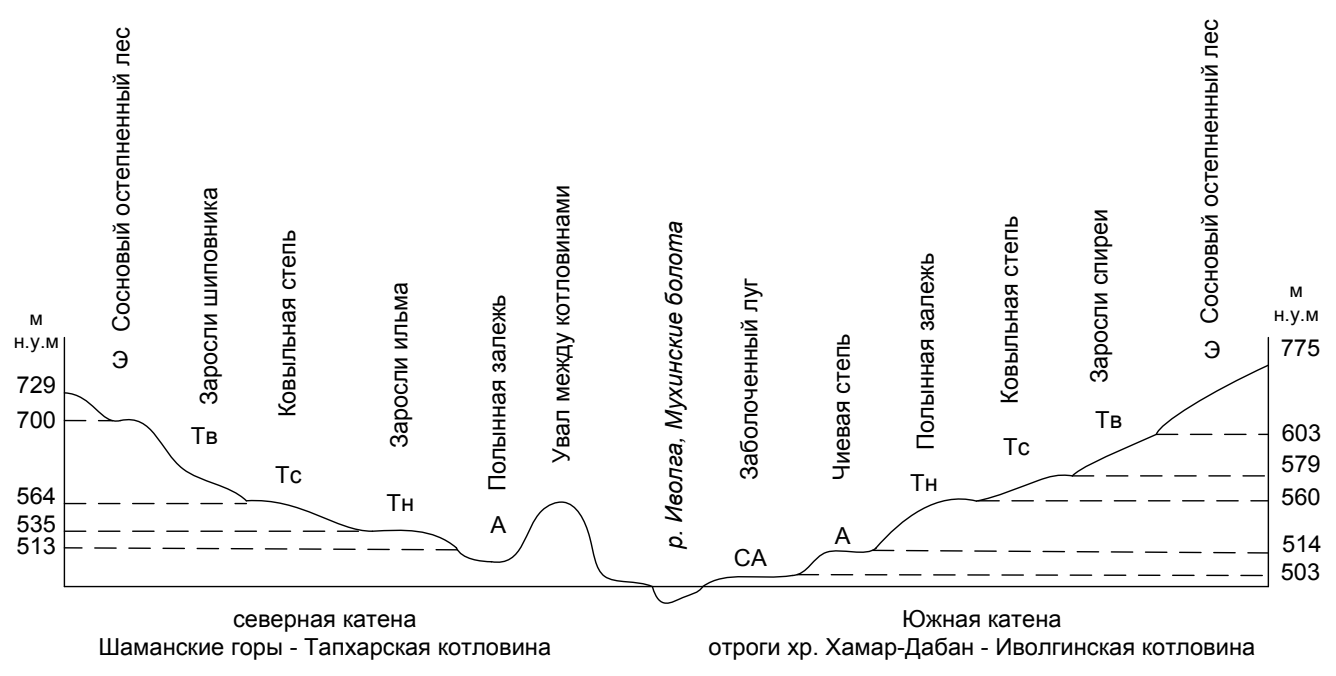

Puc. 2. Катены на поперечном профиле в средней части р. Иволга.

Примечание: Северная катена «Шаманские горы - Тапхарская котловина». Южная катена «Отроги хр. Хамар-Дабан — Иволгинская котловина».

Позиции в катене: CA — супераквальная, А — аккумулятивная, Тн — транзитная нижняя, Тc — транзитная средняя, Тв — транзитная верхняя, Э — элювиальная.

КОМПЛЕКСЫ ЖУЖЕЛИЦ НА СЕВЕРНОЙ КАТЕНЕ «ШАМАНСКИЕ ГОРЫ — ТАПХАРСКАЯ КОТЛОВИНА»

ЭлювИАльНАЯ ПОЗИция. Комплекс Жужелиц соснового остепненного редкостойного леса (Т 12), приуроченный к вершине Шаманских гор (729 м н.у.м), отличается бедным разнообразием (17 видов), низкой численностью жуков (212 экз.) и их уловистостью за сезон (0,15 экз. / лов.-сут.). В структуре доминантов преобладают в основном степные виды Harpalus heyrovskyi (31\%), Poecilus gebleri (21\%), P. fortipes (19\%), субдоминантов - Curtonotus fodinae (8\%), Carabus kruberi (7\%). Остальные виды редкие и единичные: Carabus canaliculatus, C. glyptopterus, Pristosia nitidula, 
Poecilus major, Pseudotaphoxenus dauricus, Agonum impressum, Harpalus calceatus, H. major, H. brevicornis, H. pallidipennis, H. erosus, Cymindis binotata.

ТРАНЗИТНАЯ ПОЗИЦИЯ. В ее верхней части приурочен комплекс жужелиц зарослей шиповника (Т 11) на склоне Шаманских гор (700 м н.у.м). Видовое разнообразие жужелиц увеличивается до 22 видов с низкой численностью (200 экз.) и уловистостью жуков (0,1 экз. / лов.-сут.). В структуре доминирования преобладают Carabus canaliculatus (13\%), Harpalus heyrovskyi (13\%), Pseudotaphoxenus dauricus (10\%), H. vittatus (10\%), субдоминантов - присутствуют H. brevicornis (9\%), H. vittatus (9\%), Cymindis binotata (9\%), Curtonotus fodinae (7\%), H. viridanus (5\%). Преобладают в основном степные виды, кроме лесного Carabus canaliculatus. В средней части позиции распространен комплекс жужелиц ковыльной степи (Т 10) в Тапхарской котловине (564 м н.у.м). Видовой состав жужелиц представлен 20 видами, численность жуков резко увеличивается в 6 раз (1950 экз.) и повышается их уловистость $(1,4$ экз. / лов.-сут.). В структуре доминирования представлены Harpalus pallidipennis (31\%), H. lumbaris (23\%), Cymindis binotata (20\%), Poecilus gebleri (11\%). В нижней части позиции характерен комплекс жужелиц зарослей ильмовников (Т 8) в Тапхарской котловине (535 м н.у.м). Видовой состав жужелиц представлен 21 видом с высокой численностью (2047 экз.) и уловистостью жуков (1,5 экз. / лов.-сут.). В качестве доминантов представлены степные виды Poecilus gebleri (47\%), Cymindis binotata (20\%), Carabus glyptopterus (11\%), H. lumbaris (11\%).

Аккумулятивная позиция. Комплекс жужелиц полынной залежи (Т 7) на солончаках, приуроченный к днищу Тапхарской котловины (513 м н.у.м.), характеризуется бедным видовым составом (17 видов) в связи с высокой степенью засоления, отмечено сокращение численности жуков (1158 экз.) и их уловистости за сезон $(1,1$ экз. / лов.-сут.). В структуре доминантов отмечены Harpalus lumbaris (27\%), Poecilus gebleri (19\%), Carabus glyptopterus (18\%), H. viridanus (18\%).

КОМПЛЕКСЫ ЖУЖЕЛИЦ НА ЮЖНОЙ КАТЕНЕ «ХРЕБЕТ ХАМАР-ДАБАН — ИВОЛГИНСКАЯ КОТловИНА»

ЭлювиАльНАЯ Позиция. Комплекс жужелиц соснового остепненного редкостойного леса (ТНИ1), приуроченного к южным отрогам хр. Хамар-Дабан (775 м н.у.м), отличается бедным разнообразием (16 видов) с низкой численностью (147 экз.) и уловистостью жуков за сезон (0,11 экз. / лов.-сут.). В структуре доминантов представлены степные виды Poecilus gebleri (33\%), P. fortipes (19\%), Carabus kruberi (13\%).

ТРАНЗИТНАЯ ПОЗИЦИя. В верхней части позиции распространен комплекс жужелиц зарослей спиреи (ТНИ 2) на южном склона хр. Хамар-Дабан (603 м н.у.м). Видовое разнообразие жужелиц составляет 27 видов с низкой численностью (323 экз.) и низкой уловистостью $(0,2-0,2$ экз. / лов.-сут.). В структуре доминантов преобладают Pseudotaphoxenus dauricus (29\%), Cymindis binotata (15\%), Poecilus gebleri (12\%), субдоминантов - H. lumbaris (9\%), H. froelichi (8\%), Carabus kruberi (7\%). Средняя часть позиции занята комплексом жужелиц ковыльно-полынно-лапчатковой степи (ТНИ4) на южном склоне хр. Хамар-Дабан (579 м н.у.м). Видовой состав жужелиц представлен 22 видами с низкой численностью (365 экз.) и уловистостью $(0,2$ экз. $/$ лов.-сут.). В структуру доминантов входят Cymindis binotata (30\%), Harpalus lumbaris (23\%), Poecilus gebleri (21\%), субдоминантов - Corsyra fusula (8\%). В нижней 
Л. Ц. Хобракова. Бассейновый подход к изучению пространственной организации жуковжужелиц (на примере бассейна реки Иволга - бассейна озера Байкал)

части позиции распространен комплекс жужелиц полынных засоленных залежей (ТНИ5) в Иволгинской котловине (560 м н.у.м). Видовое разнообразие жужелиц возрастает до 28 видов, резко увеличивается численность жуков (4109 экз.) и отмечена высокая уловистость за сезон (3,3 экз. / лов.-сут.). Среди жужелиц преобладают исключительно степные виды. В составе доминантов отмечены Poecilus gebleri (20\%), Corsyra fusula (15\%), Harpalus pallidipennis (12\%), Cymindis binotata (11\%), субдоминантов - преобладают $H$. viridanus $(10 \%)$, H. vittatus $(8 \%)$, H. lumbaris $(8 \%)$.

АккумулятивнАЯ Позиция. Комплекс жужелиц чиевой степи на солонцах (X4), приуроченный к днищу Иволгинской котловины (514 м н. у. м.), характеризуется самым высоким разнообразием (34 вида), низкой численностью жуков (587 экз.) и их уловистостью за сезон (0,4 экз. / лов.-сут.). Такое разнообразие жужелиц, несмотря на высокую степень засоления почвы, обеспечивается контрастностью условий обитания насекомых в связи с неравномерным увлажнением, сезонной подвижностью солей в почве и развитием мощной корневой системы чия блестящего, в котором обитает почти 90\% мезопедобионтов (Хобракова и др., 2015). В видовом составе жужелиц преобладают степные и галофильные виды. В структуре доминантов представлены Poecilus gebleri (30\%), Curtonotus fodinae (19\%), субдоминантов Harpalus viridanus (9\%), H. lumbaris (7\%).

СУПЕРАКВАЛЬНАЯ ПОЗИЦИЯ. КомПлекс жужелиц разнотравно-осокового заболоченного солонцеватого луга (ТНИ8) отмечен только на солонцеватых лугах Мухинских болот (503 м н.у.м). Видовой состав жужелиц составляет 24 вида с низкой численностью (819 экз.) и низкой уловистостью за сезон (0,7 экз. / лов.-сут.). Здесь преобладают луговые и лугово-болотные виды жужелиц. В составе доминантов присутствуют Chlaenius tristis (31\%), Pterostichus planipennis (25\%), Carabus maeander (13\%), субдоминантов - Agonum impressum (7\%), Poecilus versicolor (6\%).

Таблица $3 \mathrm{a}$

Таксономический состав комплексов жужелиц на северной катенев бассейне р. Иволга

\begin{tabular}{|c|c|c|c|c|c|}
\hline \multirow{3}{*}{ Таксономический состав } & \multicolumn{5}{|c|}{$\begin{array}{c}\text { Северная катена } \\
\text { «Шаманские горы - Тапхарская котловина» }\end{array}$} \\
\hline & $Э$ & Тв & $\mathrm{Tc}$ & $\mathrm{T}_{\mathrm{H}}$ & A \\
\hline & $\begin{array}{c}\text { Tапхар } \\
12\end{array}$ & $\begin{array}{c}\text { Тапхар } \\
11\end{array}$ & $\begin{array}{c}\text { Тапхар } \\
10\end{array}$ & Тапхар 8 & Тапхар 7 \\
\hline $\begin{array}{l}\text { Cicindela coerulea nitida } \\
\text { Lichtenstein, } 1796\end{array}$ & & & & $10(0,4 \%)$ & \\
\hline C. transbaicalica Motschulsky, 1844 & & & $11(0,5 \%)$ & $9(0,4 \%)$ & \\
\hline Calosoma denticolle Gebler, 1833 & & & $11(0,5 \%)$ & $26(1,2 \%)$ & $14(1,2 \%)$ \\
\hline $\begin{array}{l}\text { C. canaliculatus canaliculatus } \\
\text { Adams, } 1812\end{array}$ & $\begin{array}{c}3 \\
(1,4 \%) \\
\end{array}$ & $\begin{array}{c}27 \\
(13,5 \%) \\
\end{array}$ & & & \\
\hline $\begin{array}{l}\text { C. kruberi } \\
\text { Fischer von Waldheim, } 1822\end{array}$ & $\begin{array}{c}15 \\
(7,1 \%) \\
\end{array}$ & $\begin{array}{c}10 \\
(5 \%) \\
\end{array}$ & & $1(0,04 \%)$ & \\
\hline $\begin{array}{l}\text { C. glyptopterus } \\
\text { Fischer von Waldheim, } 1828\end{array}$ & $3(1,4 \%)$ & $1(0,5 \%)$ & $47(2,4 \%)$ & $\begin{array}{c}226 \\
(11 \%) \\
\end{array}$ & $\begin{array}{c}209 \\
(18 \%) \\
\end{array}$ \\
\hline
\end{tabular}


ПРИРОДА ВНУТРЕННЕЙ АЗИИ

NATURE OF INNER ASIA

\begin{tabular}{|c|c|c|c|c|c|}
\hline Loricera pilicornis (Fabricius, 1775) & & & & $1(0,04 \%)$ & \\
\hline $\begin{array}{l}\text { Pristosia nitidula } \\
\text { (A. Morawitz, 1862) }\end{array}$ & $4(1,8 \%)$ & $5(2,5 \%)$ & & & \\
\hline A. violacea Motschulsky, 1844 & & $2(1 \%)$ & & & \\
\hline $\begin{array}{l}\text { Curtonotus brevicollis } \\
\text { (Chaudoir, 1850) }\end{array}$ & & & $34(17, \%)$ & $15(0,7 \%)$ & $11(0,9 \%)$ \\
\hline Curt. fodinae (Mannerheim, 1825) & $16(7,5 \%)$ & $14(7 \%)$ & $61(3,1 \%)$ & $3(0,1 \%)$ & $33(2,8 \%)$ \\
\hline Curt. giganteus (Motschulsky, 1845) & & & & $3(0,1 \%)$ & $3(0,2 \%)$ \\
\hline P. fortipes (Chaudoir, 1850) & $\begin{array}{c}41 \\
(19,3 \%) \\
\end{array}$ & $3(1,5 \%)$ & & $2(0,1 \%)$ & $7(0,6 \%)$ \\
\hline P. gebleri Dejean, 1828 & $\begin{array}{c}44 \\
(20,7 \%) \\
\end{array}$ & $9(4,5 \%)$ & $\begin{array}{c}211 \\
(10,8 \%) \\
\end{array}$ & $\begin{array}{c}968 \\
(47,2 \%) \\
\end{array}$ & $\begin{array}{c}226 \\
(19,5 \%) \\
\end{array}$ \\
\hline P. major (Motschulsky, 1844) & $1(0,4 \%)$ & & $1(0,05 \%)$ & & \\
\hline $\begin{array}{l}\text { Pseudotaphoxenus dauricus dauricus } \\
\text { (Fischer von Waldheim, 1823) }\end{array}$ & $1(0,4 \%)$ & $\begin{array}{c}20 \\
(10 \%) \\
\end{array}$ & $2(0,1 \%)$ & $8(0,3 \%)$ & $1(0,1 \%)$ \\
\hline $\begin{array}{l}\text { Agonum dolens } \\
\text { (C.R. Sahlberg, 1827) }\end{array}$ & & $2(1 \%)$ & & & \\
\hline Ag. impressum (Panzer, 1797) & $1(0,4 \%)$ & & & & \\
\hline $\begin{array}{l}\text { Harpalus calceatus } \\
\text { (Duftschmid, 1812) }\end{array}$ & $1(0,4 \%)$ & $2(1 \%)$ & $13(0,6 \%)$ & $15(0,7 \%)$ & $45(3,8 \%)$ \\
\hline H. major Motschulsky, 1850 & $3(1,4 \%)$ & & & & \\
\hline H. acupalpoides Reitter, 1900 & & & $2(0,1 \%)$ & & \\
\hline H. amariformis Motschulsky, 1844 & & $4(2 \%)$ & & & \\
\hline H. amplicollis Ménétriés, 1848 & & & $14(0,7 \%)$ & $2(0,1 \%)$ & $14(1,2 \%)$ \\
\hline H. brevicornis Germar, 1824 & $5(2,3 \%)$ & $\begin{array}{c}19 \\
(9,5 \%) \\
\end{array}$ & $15(0,7 \%)$ & $29(1,4 \%)$ & $16(1,3 \%)$ \\
\hline H. froelichi (Sturm, 1818) & & $2(1 \%)$ & $5(0,2 \%)$ & & \\
\hline H. vittatus vittatus Gebler, 1833 & & $\begin{array}{c}21 \\
(10,5 \%) \\
\end{array}$ & $3(0,1 \%)$ & $2(0,1 \%)$ & \\
\hline H. viridanus Motschulsky, 1844 & & $10(5 \%)$ & $4(0,2 \%)$ & $18(0,8 \%)$ & $\begin{array}{c}208 \\
(17,9 \%) \\
\end{array}$ \\
\hline H. pallidipennis A. Morawitz, 1862 & $1(0,4 \%)$ & $1(0,5 \%)$ & $\begin{array}{c}611 \\
(31,3 \%) \\
\end{array}$ & $67(3,2 \%)$ & $3(0,2 \%)$ \\
\hline H. heyrovskyi Jedlička, 1928 & $\begin{array}{c}66 \\
(31,1 \%) \\
\end{array}$ & 27 & & & $1(0,1 \%)$ \\
\hline H. optabilis (Dejean, 1829) & & $1(0,5 \%)$ & & & \\
\hline H. lumbaris (Mannerheim, 1825) & & $1(0,5 \%)$ & $\begin{array}{c}453 \\
(23,2 \%) \\
\end{array}$ & $\begin{array}{c}229 \\
(11,1 \%) \\
\end{array}$ & $\begin{array}{c}316 \\
(27,2 \%) \\
\end{array}$ \\
\hline H. erosus (Mannerheim, 1825) & $4(1,8 \%)$ & $1(0,5 \%)$ & & & \\
\hline H. amputatus obtusus Gebler, 1833 & & & $1(0,05 \%)$ & & $25(2,1 \%)$ \\
\hline $\begin{array}{l}\text { Corsyra fusula } \\
\text { (Steven in Dejean, 1825) }\end{array}$ & & & $54(2,7 \%)$ & $2(0,1 \%)$ & \\
\hline
\end{tabular}


Л. Ц. Хобракова. Бассейновый подход к изучению пространственной организации жуковжужелиц (на примере бассейна реки Иволга — бассейна озера Байкал)

\begin{tabular}{|l|c|c|c|c|c|}
\hline Cymindis binotata & 3 & 18 & 397 & 411 & 26 \\
Fischer von Waldheim, 1820 & $(1,4 \%)$ & $(9 \%)$ & $(20,3 \%)$ & $(20 \%)$ & $(2,2 \%)$ \\
\hline Итого & 212 & 200 & 1950 & 2047 & 1158 \\
\hline
\end{tabular}

Примечание: позиция в катене: Э — элювиальная, Тв - транзитная верхняя, Тс — транзитная средняя, Тн - транзитная нижняя, А — аккумулятивная.

Биотопы на катенах приведены в таблице 1.

Таблица $3 б$

Таксономический состав комплексов жужелиц на южной катене в бассейне р. Иволга

\begin{tabular}{|c|c|c|c|c|c|c|}
\hline \multirow{3}{*}{ Таксономический состав } & \multicolumn{6}{|c|}{$\begin{array}{c}\text { Южная катена } \\
\text { «Отроги хр. Хамар-Дабан - Иволгинская котловина» }\end{array}$} \\
\hline & $Э$ & Тв & Tc & $\mathrm{TH}_{\mathrm{H}}$ & A & $\mathrm{CA}$ \\
\hline & ТНИ1 & ТНИ2 & ТНИ4 & ТНИ5 & $\begin{array}{c}\text { Хубисхал } \\
4\end{array}$ & ТнИ8 \\
\hline $\begin{array}{l}\text { Cylindera obliquefasciata } \\
\text { M.F. Adams, } 1817\end{array}$ & & & & & $2(0,3 \%)$ & $\begin{array}{c}2 \\
(0,2 \%) \\
\end{array}$ \\
\hline $\begin{array}{l}\text { C. mongolica } \\
\text { (Faldermann, 1835) }\end{array}$ & & & $\begin{array}{c}1 \\
(0,2 \%) \\
\end{array}$ & & & \\
\hline C. gracilis (Pallas, 1773) & & $\begin{array}{c}1 \\
(0,3 \%)\end{array}$ & & & & \\
\hline $\begin{array}{l}\text { Calosoma denticolle Gebler, } \\
1833\end{array}$ & & $\begin{array}{c}9 \\
(2,7 \%) \\
\end{array}$ & $\begin{array}{c}3 \\
(0,8 \%) \\
\end{array}$ & $\begin{array}{c}105 \\
(2,5 \%)\end{array}$ & $12(2 \%)$ & $\begin{array}{c}1 \\
(0,1 \%) \\
\end{array}$ \\
\hline $\begin{array}{l}\text { C. granulatus duarius } \\
\text { Fischer von Waldheim, } 1844 \\
\end{array}$ & & & & & & $33(4 \%)$ \\
\hline $\begin{array}{l}\text { C. latreillei } \\
\text { Fischer von Waldheim, } 1820\end{array}$ & & & $\begin{array}{c}1 \\
(0,2 \%) \\
\end{array}$ & & $1(0,1 \%)$ & \\
\hline $\begin{array}{l}\text { C. maeander } \\
\text { Fischer von Waldheim, } 1820\end{array}$ & & & & $\begin{array}{c}1 \\
(0,02 \%)\end{array}$ & & $\begin{array}{c}103 \\
(12,5 \%) \\
\end{array}$ \\
\hline $\begin{array}{l}\text { C. kruberi } \\
\text { Fischer von Waldheim, } 1822\end{array}$ & $\begin{array}{c}19 \\
(12,9 \%) \\
\end{array}$ & $\begin{array}{c}21 \\
(6,5 \%) \\
\end{array}$ & $\begin{array}{c}1 \\
(0,2 \%) \\
\end{array}$ & $\begin{array}{c}11 \\
(0,2 \%) \\
\end{array}$ & & \\
\hline $\begin{array}{l}\text { C. glyptopterus } \\
\text { Fischer von Waldheim, } 1828\end{array}$ & & $\begin{array}{c}1 \\
(0,3 \%)\end{array}$ & & $\begin{array}{c}62 \\
(1,5 \%) \\
\end{array}$ & $7(1,1 \%)$ & \\
\hline $\begin{array}{l}\text { Blethisa multipunctata } \\
\text { (Linnaeus, 1758) }\end{array}$ & & & & & & $\begin{array}{c}1 \\
(0,1 \%) \\
\end{array}$ \\
\hline $\begin{array}{l}\text { Elaphrus cupreus } \\
\text { Duftschmid, } 1812 \\
\end{array}$ & & & & & & $\begin{array}{c}1 \\
(0,1 \%) \\
\end{array}$ \\
\hline $\begin{array}{l}\text { Pristosia nitidula } \\
\text { (A. Morawitz, 1862) }\end{array}$ & $\begin{array}{c}6 \\
(4,1 \%) \\
\end{array}$ & & & & & \\
\hline $\begin{array}{l}\text { Amara communis } \\
\text { (Panzer, 1797) }\end{array}$ & & & & & $\begin{array}{c}1 \\
(0,1 \%) \\
\end{array}$ & \\
\hline $\begin{array}{l}\text { A. biarticulata } \\
\text { Motschulsky, } 1844\end{array}$ & & $\begin{array}{c}2 \\
(0,6 \%) \\
\end{array}$ & $\begin{array}{c}1 \\
(0,2 \%) \\
\end{array}$ & $\begin{array}{c}4 \\
(0,09 \%) \\
\end{array}$ & & \\
\hline A. violacea Motschulsky, 1844 & & & $\begin{array}{c}2 \\
(0,5 \%) \\
\end{array}$ & $\begin{array}{c}4 \\
(0,09 \%) \\
\end{array}$ & & \\
\hline $\begin{array}{l}\text { A. rupicola } \\
\text { (C. Zimmermann, 1832) }\end{array}$ & & & & & $8(1,3 \%)$ & \\
\hline
\end{tabular}


NATURE OF INNER ASIA

\begin{tabular}{|c|c|c|c|c|c|c|}
\hline $\begin{array}{l}\text { A. saginata vilis } \\
\text { Tschitscherin, } 1894\end{array}$ & & & & & $21(3,5 \%)$ & \\
\hline A. stulta Lutshnik, 1935 & & & & & $1(0,1 \%)$ & \\
\hline A. apricaria (Paykull, 1790) & & & & & $1(0,1 \%)$ & \\
\hline $\begin{array}{l}\text { A. abdominalis } \\
\text { (Motschulsky, 1844) }\end{array}$ & & & & & $5(0,8 \%)$ & \\
\hline $\begin{array}{l}\text { Curtonotus brevicollis } \\
\text { (Chaudoir, 1850) }\end{array}$ & & & & & $6(1 \%)$ & \\
\hline $\begin{array}{l}\text { Curt. dauricus } \\
\text { (Motschulsky, 1844) }\end{array}$ & & & & & & $\begin{array}{c}22 \\
(2,6 \%) \\
\end{array}$ \\
\hline Curt. dux Tschitscherin, 1894 & & $\begin{array}{c}3 \\
(0,9 \%) \\
\end{array}$ & $\begin{array}{c}2 \\
(0,5 \%) \\
\end{array}$ & $6(0,1 \%)$ & & \\
\hline $\begin{array}{l}\text { Curt. fodinae } \\
\text { (Mannerheim, 1825) }\end{array}$ & $\begin{array}{c}6 \\
(4,1 \%) \\
\end{array}$ & $\begin{array}{c}5 \\
(1,5 \%) \\
\end{array}$ & $\begin{array}{c}6 \\
(1,6 \%) \\
\end{array}$ & $\begin{array}{c}77 \\
(1,8 \%) \\
\end{array}$ & $\begin{array}{c}111 \\
(18,9 \%) \\
\end{array}$ & \\
\hline $\begin{array}{l}\text { Curt. giganteus } \\
\text { (Motschulsky, 1845) }\end{array}$ & & & & & $\begin{array}{c}1 \\
(0,1 \%) \\
\end{array}$ & $\begin{array}{c}1 \\
(0,1 \%) \\
\end{array}$ \\
\hline $\begin{array}{l}\text { Curt. harpaloides } \\
\text { (Dejean, 1828) }\end{array}$ & & & & $\begin{array}{c}19 \\
(0,4 \%) \\
\end{array}$ & & \\
\hline $\begin{array}{l}\text { Poecilus versicolor } \\
\text { (Sturm, 1824) }\end{array}$ & & & & & $3(0,5 \%)$ & $\begin{array}{c}46 \\
(5,6 \%) \\
\end{array}$ \\
\hline P. fortipes (Chaudoir, 1850) & $\begin{array}{c}28 \\
(19 \%) \\
\end{array}$ & $\begin{array}{c}2 \\
(0,6 \%) \\
\end{array}$ & & $\begin{array}{c}2 \\
(0,04 \%) \\
\end{array}$ & & $\begin{array}{c}12 \\
(1,4 \%)\end{array}$ \\
\hline P. gebleri Dejean, 1828 & $\begin{array}{c}48 \\
(32,6 \%) \\
\end{array}$ & $\begin{array}{c}40 \\
(12,3 \%) \\
\end{array}$ & $\begin{array}{c}76 \\
(20,8 \%) \\
\end{array}$ & $\begin{array}{c}830 \\
(20,1 \%) \\
\end{array}$ & $\begin{array}{c}174 \\
(29,6 \%) \\
\end{array}$ & $\begin{array}{c}14 \\
(1,7 \%) \\
\end{array}$ \\
\hline P. major (Motschulsky, 1844) & & & & & & $\begin{array}{c}1 \\
(0,1 \%)\end{array}$ \\
\hline $\begin{array}{l}\text { Pterostichus eschscholtzii } \\
\text { (Germar, 1824) }\end{array}$ & & & & $\begin{array}{c}1 \\
(0,02 \%) \\
\end{array}$ & & $\begin{array}{c}12 \\
(1,4 \%) \\
\end{array}$ \\
\hline $\begin{array}{l}\text { Pt. planipennis } \\
\text { R. F. Sahlberg, } 1844\end{array}$ & & & & & & $\begin{array}{c}203 \\
(24,7 \%) \\
\end{array}$ \\
\hline $\begin{array}{l}\text { Pt. gibbicollis } \\
\text { (Motschulsky, 1844) }\end{array}$ & & $\begin{array}{c}1 \\
(0,3 \%) \\
\end{array}$ & & & & \\
\hline $\begin{array}{l}\text { Pt. laticollis } \\
\text { (Motschulsky, 1844) }\end{array}$ & & & & & & $\begin{array}{c}12 \\
(1,4 \%) \\
\end{array}$ \\
\hline $\begin{array}{l}\text { Pt. oblongopunctatus } \\
\text { (Fabricius, 1787) }\end{array}$ & & $\begin{array}{c}3 \\
(0,9 \%) \\
\end{array}$ & & & & \\
\hline Pt. adstrictus Eschscholtz, 1823 & $\begin{array}{c}1 \\
(0,6 \%) \\
\end{array}$ & & & & & \\
\hline $\begin{array}{l}\text { Pseudotaphoxenus dauricus } \\
\text { dauricus } \\
\text { (Fischer von Waldheim, 1823) }\end{array}$ & $\begin{array}{c}6 \\
(4,1 \%) \\
\end{array}$ & $\begin{array}{c}95 \\
(29,4 \%) \\
\end{array}$ & $\begin{array}{c}23 \\
(6,3 \%) \\
\end{array}$ & $43(1 \%)$ & & \\
\hline Ag. impressum (Panzer, 1797) & & $\begin{array}{c}1 \\
(0,3 \%) \\
\end{array}$ & & & & $\begin{array}{c}55 \\
(6,7 \%) \\
\end{array}$ \\
\hline $\begin{array}{l}\text { Bradycellus glabratus } \\
\text { (Reitter, 1894) }\end{array}$ & & & & $\begin{array}{c}1 \\
(0,02 \%)\end{array}$ & & \\
\hline $\begin{array}{l}\text { Harpalus calceatus } \\
\text { (Duftschmid, 1812) }\end{array}$ & $\begin{array}{c}2 \\
(1,3 \%) \\
\end{array}$ & $\begin{array}{c}7 \\
(2,1 \%) \\
\end{array}$ & $\begin{array}{c}4 \\
(1,1 \%) \\
\end{array}$ & $\begin{array}{c}34 \\
(0,8 \%) \\
\end{array}$ & $\begin{array}{c}16 \\
(2,7 \%) \\
\end{array}$ & $\begin{array}{c}2 \\
(0,2 \%) \\
\end{array}$ \\
\hline
\end{tabular}


Л. Ц. Хобракова. Бассейновый подход к изучению пространственной организации жуковжужелиц (на примере бассейна реки Иволга — бассейна озера Байкал)

\begin{tabular}{|c|c|c|c|c|c|c|}
\hline H. pusillus Motschulsky, 1850 & $\begin{array}{c}1 \\
(0,6 \%) \\
\end{array}$ & & $\begin{array}{c}2 \\
(0,5 \%) \\
\end{array}$ & $\begin{array}{c}5 \\
(0,1 \%) \\
\end{array}$ & $\begin{array}{c}6 \\
(1 \%) \\
\end{array}$ & \\
\hline H. acupalpoides Reitter, 1900 & & & & & $2(0,3 \%)$ & \\
\hline $\begin{array}{l}\text { H. amariformis } \\
\text { Motschulsky, } 1844\end{array}$ & & $\begin{array}{c}1 \\
(0,3 \%)\end{array}$ & $\begin{array}{c}2 \\
(0,5 \%) \\
\end{array}$ & & $\begin{array}{c}6 \\
(1 \%) \\
\end{array}$ & \\
\hline H. amplicollis Ménétriés, 1848 & & $\begin{array}{c}2 \\
(0,6 \%)\end{array}$ & & $\begin{array}{c}99 \\
(2,4 \%)\end{array}$ & $\begin{array}{c}3 \\
(0,5 \%)\end{array}$ & \\
\hline H. tichonis Jacobson, 1907 & & & & $\begin{array}{c}1 \\
(0,02 \%)\end{array}$ & $\begin{array}{c}6 \\
(1 \%) \\
\end{array}$ & \\
\hline $\begin{array}{l}\text { H. macronotus } \\
\text { Tschitscherine, } 1893\end{array}$ & & $\begin{array}{c}1 \\
(0,3 \%)\end{array}$ & & & & \\
\hline H. brevicornis Germar, 1824 & $\begin{array}{c}7 \\
(4,7 \%) \\
\end{array}$ & $\begin{array}{c}10 \\
(3,1 \%) \\
\end{array}$ & $\begin{array}{c}7 \\
(1,9 \%) \\
\end{array}$ & $\begin{array}{c}149 \\
(3,6 \%) \\
\end{array}$ & $\begin{array}{c}16 \\
(2,7 \%) \\
\end{array}$ & $\begin{array}{c}1 \\
(0,1 \%) \\
\end{array}$ \\
\hline H. froelichi (Sturm, 1818) & & $\begin{array}{c}25 \\
(7,7 \%) \\
\end{array}$ & $\begin{array}{c}5 \\
(1,3 \%) \\
\end{array}$ & $\begin{array}{c}23 \\
(0,5 \%) \\
\end{array}$ & $\begin{array}{c}14 \\
(4,8 \%) \\
\end{array}$ & \\
\hline H. solitaris (Dejean, 1829) & & & & & $1(0,1 \%)$ & \\
\hline H. vittatus vittatus Gebler, 1833 & & $\begin{array}{c}2 \\
(0,6 \%) \\
\end{array}$ & $\begin{array}{c}1 \\
(0,2 \%) \\
\end{array}$ & $\begin{array}{c}345 \\
(8,3 \%) \\
\end{array}$ & $\begin{array}{c}17 \\
(2,8 \%) \\
\end{array}$ & \\
\hline H. fuscipalpis (Sturm, 1818) & & & & & $3(0,5 \%)$ & \\
\hline H. viridanus Motschulsky, 1844 & $\begin{array}{c}3 \\
(2 \%) \\
\end{array}$ & $\begin{array}{c}1 \\
(0,3 \%)\end{array}$ & $\begin{array}{c}1 \\
(0,2 \%) \\
\end{array}$ & $\begin{array}{c}421 \\
(10,2 \%) \\
\end{array}$ & $\begin{array}{c}52 \\
(8,8 \%) \\
\end{array}$ & \\
\hline $\begin{array}{l}\text { H. pallidipennis } \\
\text { A. Morawitz, } 1862\end{array}$ & & $\begin{array}{c}4 \\
(1,2 \%) \\
\end{array}$ & $\begin{array}{c}3 \\
(0,8 \%) \\
\end{array}$ & $\begin{array}{c}476 \\
(11,5 \%)\end{array}$ & $\begin{array}{c}4 \\
(0,6 \%) \\
\end{array}$ & \\
\hline $\begin{array}{l}\text { H. aequicollis } \\
\text { Motschulsky, } 1844\end{array}$ & $\begin{array}{c}6 \\
(4,1 \%) \\
\end{array}$ & & & & $\begin{array}{c}2 \\
(0,3 \%) \\
\end{array}$ & \\
\hline H. heyrovskyi Jedlička, 1928 & $\begin{array}{c}1 \\
(0,6 \%) \\
\end{array}$ & & & & & \\
\hline H. optabilis (Dejean, 1829) & $\begin{array}{c}2 \\
(1,3 \%)\end{array}$ & & $\begin{array}{c}3 \\
(0,8 \%)\end{array}$ & & & \\
\hline $\begin{array}{l}\text { H. lumbaris } \\
\text { (Mannerheim, 1825) }\end{array}$ & & $\begin{array}{c}28 \\
(8,6 \%) \\
\end{array}$ & $\begin{array}{c}82 \\
(22,4 \%) \\
\end{array}$ & $\begin{array}{c}325 \\
(7,9 \%) \\
\end{array}$ & $\begin{array}{c}39 \\
(6,6 \%) \\
\end{array}$ & \\
\hline H. affinis (Schrank, 1781) & & & & & & $\begin{array}{c}8 \\
(0,9 \%) \\
\end{array}$ \\
\hline H. erosus (Mannerheim, 1825) & $\begin{array}{c}7 \\
(4,7 \%)\end{array}$ & & & & & \\
\hline $\begin{array}{l}\text { H. amputatus obtusus } \\
\text { Gebler, } 1833\end{array}$ & & $\begin{array}{c}1 \\
(0,3 \%)\end{array}$ & & & $\begin{array}{c}22 \\
(3,7 \%)\end{array}$ & $\begin{array}{c}1 \\
(0,1 \%)\end{array}$ \\
\hline $\begin{array}{l}\text { H. distinguendus distinguendus } \\
\text { (Duftschmid, 1812) }\end{array}$ & & & & & & $\begin{array}{c}1 \\
(0,1 \%) \\
\end{array}$ \\
\hline $\begin{array}{l}\text { Neophygas microcephalus } \\
\text { (Faldermann, 1835) }\end{array}$ & & & & $\begin{array}{c}3 \\
(0,07 \%)\end{array}$ & & \\
\hline $\begin{array}{l}\text { Harpalus (s. str.) torridoides } \\
\text { Reitter, } 1900\end{array}$ & & $\begin{array}{c}6 \\
(1,8 \%) \\
\end{array}$ & & & & \\
\hline $\begin{array}{l}\text { Masoreus wetterhallii } \\
\text { Gyllenhal, } 1813\end{array}$ & & & & & $1(0,1 \%)$ & \\
\hline
\end{tabular}




\begin{tabular}{|c|c|c|c|c|c|c|}
\hline $\begin{array}{l}\text { Syntomus mongolicus } \\
\text { (Motschulsky, 1844) }\end{array}$ & & & & & $11(1,8 \%)$ & \\
\hline $\begin{array}{l}\text { Corsyra fusula } \\
\text { (Steven in Dejean, 1825) }\end{array}$ & & $\begin{array}{c}3 \\
(0,9 \%)\end{array}$ & $\begin{array}{c}29 \\
(7,9 \%)\end{array}$ & $\begin{array}{c}622 \\
(15,1 \%)\end{array}$ & & \\
\hline $\begin{array}{l}\text { Chlaenius stschukini } \\
\text { Ménétriés, } 1837\end{array}$ & & & & & & $\begin{array}{c}32 \\
(3,9 \%)\end{array}$ \\
\hline $\begin{array}{l}\text { Ch. tristis reticulatus } \\
\text { Motschulsky, } 1844\end{array}$ & & & & & & $\begin{array}{c}252 \\
(30,7 \%)\end{array}$ \\
\hline Ch. alutaceus Gebler, 1829 & & & & & & $\begin{array}{c}3 \\
(0,3 \%)\end{array}$ \\
\hline $\begin{array}{l}\text { Cymindis binotata } \\
\text { Fischer von Waldheim, } 1820\end{array}$ & $\begin{array}{c}4 \\
(2,7 \%)\end{array}$ & $\begin{array}{c}48 \\
(14,8 \%)\end{array}$ & $\begin{array}{c}110 \\
(30,1 \%)\end{array}$ & $\begin{array}{c}440 \\
(10,7 \%)\end{array}$ & $12(2 \%)$ & \\
\hline Итого & 147 & 323 & 365 & 4109 & 587 & 819 \\
\hline
\end{tabular}

Примечание: позиция в катене: Э — элювиальная, Тв - транзитная верхняя, Тс - транзитная средняя, Тн - транзитная нижняя, А - аккумулятивная, CA - супераквальная. Биотопы на катенах приведены в таблице 1.

\section{Заключение}

Использование бассейновой концепции имеет ряд преимуществ при изучении пространственной организации насекомых в горно-котловинных условиях и переходной лесостепной зоне. На примере бассейна малой р. Иволга показаны способы систематизации данных о жужелицах на основе гидрологической сети ее притоков Халюта и Большая Речка, Мухинских болот и бессточной Тапхарской котловины.

Фауна жужелиц бассейна р. Иволга достаточно богата (148 видов из 32 родов), что характерно для лесостепной переходной зоны в бассейне оз. Байкал. В бассейне p. Иволга в условиях недостатка влаги и засоления почв в верховье реки доминируют лугово-болотно-лесные комплексы жужелиц с богатым разнообразием, в средней и нижней частях бассейна преобладают аридные сухостепные комплексы жужелиц с бедным разнообразием, но высокой численностью жуков. На водоразделах р. Иволга выявлен бедный видовой состав с низкой численностью и уловистостью жужелиц, на склонах и в пойме состав жуков становится более разнообразным с высокой численностью и уловистостью, здесь преобладают степные галофильные комплексы жужелиц. В целом комплексы жужелиц бассейна р. Иволга характерны для аридных степных и пустынно-степных территорий Монголии.

Бассейновый подход позволил на уровне урочищ выявить основные ландшафтные комплексы жужелиц от истока до устья р. Иволга. Наибольшее разнообразие жужелиц отмечено в верховье реки - Верхне-Иволгинском лугово-болотно-лесном урочище в южных отрогах хр. Хамар-Дабан (102 вида), затем разнообразие жужелиц резко сокращается в Мухинском лугово-болотном урочище (34 вида), далее в низовье реки разнообразие жужелиц вновь увеличивается в Нижниволгинском лугово-степном галофитном урочище (76 видов). На притоках р. Иволга видовое разнообразие жужелиц сокращается. Так, в бассейне р. Большая Речка в Большереченском лесостепном урочище насчитывается 53 вида, а в бессточном бассейне Тапхарского степного урочища - 55 видов. В Тапхарском степном урочище выявлена наибольшая доля степных жужелиц, которые, вероятно, проникли из Монголии 
Л. Ц. Хобракова. Бассейновый подход к изучению пространственной организации жуковжужелиц (на примере бассейна реки Иволга — бассейна озера Байкал)

по Селенгинскому миграционному коридору. На уровне урочищ удобно проводить мониторинговые исследования фауны и экологии видов. Так, наибольшей антропогенной нагрузке подвержено Нижнеиволгинское лугово-степное галофитное урочище в связи с интенсивным хозяйственным освоением Иволгинской котловины (распашка, залежи, выпас скота, строительство) и природно-климатическими изменениями в виде многолетней засухи, пожаров, что приводит к дальнейшему иссушению и засолению почв местных экосистем. Полученные эталонные данные о ландшафтных комплексах жужелиц бассейна р. Иволга в 2009 г. могут стать основой дальнейших исследований.

На уровне катен выявлена смена ландшафтных комплексов жужелиц от водораздела до поймы р. Иволга. На сухих водоразделах, на элювиальной позиции обеих катен, занятых сосновыми остепененными лесами, наблюдается бедный видовой состав жужелиц (16-17 видов), низкая численность (пара сотен экземпляров жуков) и низкая уловистость жуков (0,1-0,2 экз. / лов.-сут.). Также низкое разнообразие жужелиц выявлено на полынной солончаковой залежи, приуроченной к аккумулятивной позиции в Тапхарской котловине. Наиболее богатый видовой состав жужелиц выявлен в чиевой засоленной степи аккумулятивной позиции в Иволгинской котловине. Высокая численность и высокая уловистость жужелиц зарегистрирована в транзитной нижней позиции обеих катен - в зарослях ильмовника в Тапхарской котловине и на полынной засоленной залежи в Иволгинской котловине. В структуре доминирования почти во всех позициях катен преобладают степные виды жужелиц, особенно из родов Harpalus и Poecilus.

Таким образом, речной бассейн является основой изучения биоразнообразия, разработки схем природного районирования, картирования и реконструирования возможных путей формирования фауны, прогноза распространения видов, создания сети ООПТ и рационального использования природных ресурсов.

\section{Благодарности}

Исследования выполнены за счет средств проекта «Реакичи животного мира Байкальского региона на глобальные изменения климата» (Регистрационный номер: AAAA-A17-117011810035-6; ФАНО 0337-2016-0002).

\section{Литература}

Бевз В.Н., Горбунов А.С., Быковская О.П., Прохорова О. В. Бассейновый подход к организации ландшафтных памятников природы Центрального Черноземья // Вестник ВГУ. Сер. География. Геоэкология. 2014. № 4. С. 18-25.

Гиляров М.С. Зоологический метод диагностики почв. М.: Наука, 1965. 281 с.

Имехенова Т.К. Биотопическое размещение жужелиц (Coleoptera, Carabidae) в предгорьях хребта Хамар-Дабан. Фауна и экология насекомых Забайкалья. Улан-Удэ, 1980. С. 18-24.

Корытный Л. М., Потапова Е. В. Экологические основы природопользования: учеб. пособие для СПО. 2-е изд., испр. и доп. Иркутск: Изд-во Иркутского гос. ун-та, 2018. 374 с.

Мильков Ф.Н. Бассейн реки как парадинамическая ландшафтная система и вопросы природопользования // География и природные ресурсы. 1981. № 4. С. 11-18.

Мордкович В.Г. Основы биогеографии. М.: Товарищество научных изданий КМК, 2005. $236 \mathrm{c}$.

Мордкович В.Г., Любечанский И.И. Зонально-катенный порядок // Успехи современной биологии. 1998. № 118(2). С. 205-215. 
Теоретические и методические проблемы сравнительной флористики / отв. ред. Б. А. Юрцев // Материалы II рабочего совещания по сравнительной флористике. Л.: Наука, 1987. 283 с.

Фиськов А.П. К вопросу о бассейновом уровне организации в биосфере // Общие проблемы биоценологии. М., 1986. С. 50-51.

Хобракова Л.Ц. Локальная фауна и сообщества жуков-жужелиц (Coleoptera, Carabidae) в Тапхарской котловине (Западное Забайкалье) // Вестник БГУ. Сер. Биология, география. 2012. № 4. С. 166-170.

Хобракова Л.Ц., Лаврентьева И.Н., Данилов С.Н., Убугунов Л. Л., Убугунова В. И., Зайцева С. В. Беспозвоночные животные чиевой степи на солонцах Забайкалья: пространственновременная структура // Сибирский экологический журнал. 2015. № 1. С. 89-101.

Хобракова Л. Ц., Шиленков В. Г., Дудко Р. Ю. Жуки-жужелицы (Coleoptera, Carabidae) Бурятии. Улан-Удэ: Изд-во БНЦ СО РАН, 2014. 380 с.

Хортон Р.Е. Эрозионное развитие рек и водосборных бассейнов // Гидрофизический подход к количественной морфологии: пер. с англ. М.;-Л.; Изд-во иностр. литературы, 1948. 158 с. Шарова И. Х. Жизненные формы жужелиц (Coleoptera, Carabidae). М.: Наука, 1981. 360 с. Шереметова С.А. Применение бассейновой концепции при изучении флоры (на примере Горной Шории) // Вестник КемГУ. Биология. 2013. № 1. С. 26-32.

\title{
BASIN APPROACH TO THE STUDY OF THE SPATIAL ORGANIZATION OF GROUND BEETLES (A CASE OF THE IVOLGA RIVER BASIN — LAKE BAIKAL BASIN)
}

\section{Ts. Khobrakova}

\author{
Larisa Ts. Khobrakova \\ Cand. Sci. (Biol.), \\ Institute for General and Experimental Biology SB RAS \\ 6 Sakhyanovoy St., Ulan-Ude 670047, Russia \\ E-mail:khobrakova77@mail.ru
}

The ground beetles fauna of the Ivolga river basin is typical for the transitional forest steppe zone between the Siberian taiga and the Mongolian steppe, which formed at the junction of the Khamar-Daban ridge and the Selenga Middle Mountains. It was identified 148 species of ground beetles from 32 genera. Based on the basin concept, we have studied the spatial organization of ground beetles in the Ivolga river basin (Selenga river — Lake Baikal basin system) in Western Transbaikal, identified the landscape complexes of ground beetles from the source to the mouth of the river and from the watershed to the flood of the river. In the first case, zoning of the Ivolga River basin was carried out on the basis of local faunas of ground beetles and faunistic relations between them. We have revealed five landscape complexes of ground beetles at the level of natural boundaries: Upper Ivolga meadow-march-forest, Mukha meadow-march, Lower Ivolga meadow-steppe halophytic, Bolshaya Rechka forest-steppe and Tapkhar steppe. The ground beetles fauna of the Upper Ivolga natural boundary is the richest (102 species), and forest species prevail in it, which are confined to the upper reaches of Ivolga River on the southern slope of the Khamar-Daban ridge. A relic of deciduous forests Carabus smaragdinus (Fischer von Waldheim, 1823) lives under the conditions of increased humidity. The species composition of ground beetles of the Mukha natural boundary is poor (34 species), it is a transitional fauna between the Upper Ivolga and the Lower Ivolga natural boundaries. Meadow and swamp species of ground beetles prevail on the banks of the Mukha Marsh. In the Lower Ivolga natural boundary steppe, meadow and halophytic species of 
Л. Ц. Хобракова. Бассейновый подход к изучению пространственной организации жуковжужелиц (на примере бассейна реки Иволга — бассейна озера Байкал)

ground beetles (76 species) are widespread, in the Bolshaya Rechka (53 species) and Tapkhar (55 species) natural boundaries — steppe species, which probably penetrated from Mongolia along the Selenga migration corridor. In the second case, we have revealed the catena change of ground beetle complexes from the watershed to the river floodplain on the north and south catenas. The ground beetles complexes in the eluvial position (EL) of both catenas in pine dry forests are characterized by poor species composition of the ground beetles (16-17 species), low number (a couple hundred copies of beetles) and low catch of beetles per season $(0,1-0,2$ copies / trap / day). The highest number and high catchability (4109 copies, 3,3 copies / trap / day) of ground beetles was registered in the complex of the transit position $(\mathrm{T})$ of the southern catena in the hollow deposit. A relatively rich species composition (34 species) was found in the complex of ground beetles of the accumulation (A) position of the southern catena in the cheegrass steppe on the solonetz soil. Steppe species and halophilic ground beetle species, especially those from the genera Harpalus and Poecilus, prevail in the structure of dominance in almost all positions of catenas. Arid forest steppe complexes of ground beetles are formed in the conditions of dry climate, lack of soil moisture and salinization in the Ivolga river basin. Keywords: basin approach; Ivolga river basin; Western Transbaikal; Selenga Middle Mountains; the Khamar-Daban Ridge, ground beetles (Coleoptera, Carabidae); zoning; natural boundary. 